\title{
"This World of Ours": The Bily Clocks and Cosmopolitan Regionalism, 1913-1948
}

\author{
BARBARA CHING
}

BETWEEN 1913 AND 1948, brothers Frank and Joseph Bily (pronounced bee-lee) carved 19 massive wooden clocks (the largest measure over nine feet tall and weigh up to 500 pounds) on their Ridgeway, Iowa, farm, about four miles north of Spillville and twelve miles west of Decorah. Founded in 1849 by Joseph Spielman, a German immigrant, Spillville was settled in the 1850s and '60s by Czech immigrants, including John Bily and Mary Andera, parents of Frank and Joseph. In 1893 Jan Joseph Kovarik, Spillville native and student of Czech composer Antonin Dvořák, persuaded his teacher to take respite from the urban intensity of his American sojourn at New York's National Conservatory of Music. Promising him a Czech-speaking population and a rural setting evocative of the Bohemian countryside, Kovarik brought the composer and his family to Spillville for a splendid summer. ${ }^{1}$ While in Spillville, Dvořák edited his most

I thank the State Historical Society of Iowa for a grant that allowed me to spend several days in Spillville and in the State Historical Society of Iowa libraries. In particular, I am grateful to Kevin Knoot and Mary Bennett at the library in Iowa City and Rosie Springer in Des Moines.

1. After returning to New York City, Dvořák said, "Spillville is an ideal place. I would like to spend the rest of my days there." Juanita J. Loven, Dvorak in Spillville: 100 Days, 100 Years Ago, 1893-1993 (Spillville, 1993), 45. For a detailed history of Spillville through 1900, see Cyril M. Klimesh, They Came to This Place: A History of Spillville, Iowa and Its Czech Settlers, 2nd ed. (Sebastapol, CA, 1992). See also Becky Neuzil and Beatrice Sbiral, The Quasquicentennial History Book, 1860-1985: Spillville, Iowa (n.p., 1985).

THE ANNALS OF IOWA 68 (Spring 2009). (C) The State Historical Society of Iowa, 2009. 
famous work, the New World Symphony, which would have its premiere at Carnegie Hall that winter. Although Joseph (18801964) and Frank (1884-1965) were young boys at the time, Spillville's association with Dvořák shaped their careers as well as their town's history.

Voracious readers, Joseph and Frank Bily received no formal education beyond the fifth grade. Museum guides tell visitors that the brothers never traveled farther than 20 miles from their farm near Ridgeway, Iowa, although a photograph on display at the museum shows that they had a Model T. ${ }^{2}$ They spoke Czech at home and, according to local lore, seldom socialized, although they did attend Saint Wenceslaus Catholic Church in Spillville. Neither brother ever married, but they had family responsibilities to their two siblings: a younger sister, Anna, also unmarried, who collected the entrance fees to their museum; and Johnny, the oldest child, who was mentally disabled. They farmed with their father until the late 1920s, when they began to rent their land to other farmers. Johnny died in 1932, their father died in 1941, and Anna died in 1943. They lived in the farmhouse until their mother died in 1949; then they moved to Spillville. They worked as carpenters in the area, and at times they worked for the county to help pay their property taxes. They always carved, even as schoolboys. Frank's schoolroom desk, transformed by his knife into a plaque depicting the holy family framed by vines and ogives, shows remarkable skill. As adults, they took up clock case carving in 1913 after a neighbor asked them to help install a clock mechanism in one of his carving projects.

2. The car appears to be a 1919 model. See Beverly Rae Kimes et al., Standard Catalog of American Cars, 1805-1942, 3rd ed. (Iola, WI, 1996), 582. I thank my colleague James Newcomb for this reference.

3. Much of this biographical information comes from the pamphlet developed by the Bily Clock Museum, The Bily Clocks of Spillville Iowa (n.p., n.d.), 2. The current (unnumbered) edition was "revised and written by Carol Riehle" in 2001. Although earlier versions of the pamphlet are unsigned, Duane Hutchinson, in Bily Brothers: Wood Carvers and Clock Makers (Lincoln, NE, 1993), xxiii, credits Blanche Beall of the West Union Gazette. Hutchinson consulted all available documentation to tell the story of the brothers by imagining the diary their mother, Mary Bily, would have written. This creative nonfiction does an excellent job of placing the Bilys' work in the context of important international, regional, and local events. Hutchinson's discussion of the clocks focuses on chronology and description rather than interpretation. 
In 1947 the Bilys moved their clocks to the building on Spillville's Main Street in which Dvořák had lived. They eventually left the collection to the village, stipulating that it be kept intact and permanently housed there. The site is now called the Bily Clock Museum, although it also includes a Dvořák exhibit on the second floor. With this relocation, the Bilys allied their work with the European cultural traditions that Dvořák epitomized. But now the economic and geographic isolation of Spillville, where time, it seems, stands still, overshadows the Bilys' ambition, tacitly placing the brothers in a provincial town where they whittled away the hours, unlike, say, the big city-bound bright young Iowans imagined by the Bilys' contemporary, Cedar Rapids-born cosmopolite Carl Van Vechten, in his 1924 novel the Tattooed Countess. The narrator explicitly uses the image of woodcarving to describe "this provincial community where ... the young went away as soon as possible to carve out their lives elsewhere." ${ }^{4}$ Indeed, such an exodus rapidly diminished the rural population throughout the twentieth century; as early as the 1920 census, over half of Americans lived in urban areas (a benchmark not reached in Iowa until the 1950 census).

From its inception, nearly all of the museum's visitors came from elsewhere to see the clocks. For this audience, the museum's curatorial materials accent nostalgia for a slower-paced experience of time. The objects displayed on the museum's secondfloor landing reinforce this nostalgia, including "unusual items of pioneer time" and "donated memories" from anonymous visitors. The pamphlet sold at the museum also stresses the backward glance, asserting that "one can easily turn back the clock to the days when Antonin Dvorák found peace and inspiration in the Spillville scene." Offering a chronological and descriptive discussion of the creation of the clocks, this pamphlet presents the Bilys as farmers first and hobbyists, carving to while away long winters, second. ${ }^{5}$

4. Carl Van Vechten, The Tattooed Countess (1924; reprint, Iowa City, 1987), 91.

5. Bily Clocks of Spillville, 2. Czech American essayist Patricia Hampl, who visited the museum to retrace Dvořák's steps, disappointedly catalogued the museum's jumble in Spillville (Minneapolis, 1987). "I move from case to case, forgetting Dvořák, carried on the pure wave of eccentricity. This is the human mind displaying itself, revealing its central capacity which turns out to be not curiosity, after all, but avidity" (67). Even though she disliked the museum, 
Just as urbanization has shaped the way we see Spillville and the clock museum, the work of Grant Wood, a near contemporary of the Bilys (1891-1942), has shaped the way we see Iowa art and Iowa artists of this period. James M. Dennis has argued that "regionalism" served as a critical label that obscured significant modernist characteristics of Wood, Benton, and Curry (and blurred important distinctions among them). ${ }^{6}$ Yet art historians still focus on Wood's antimodernism, and his work is framed that way for the art-viewing public. Writing for the Cedar Rapids Museum of Art's 2005 Grant Wood retrospective, Wanda Corn argued that Wood's art stages "narratives of confrontation" in which modern technology exerts an "invasive force" in the lives of his subjects. ${ }^{7}$ Likewise, the wall text in the gallery where American Gothic is displayed at the Art Institute of Chicago explains that "American Regionalists such as Grant Wood ... eschewed European modernist innovation and instead employed a naturalistic and narrative style of painting that appealed to a broad audience." Undoubtedly, Wood shaped his public image with a geographic contrast between milk pails and wine glasses that can readily be associated with a preference for the rural and the old-fashioned. In a 1936 interview with the New York Herald Tribune, Wood described his fruitless haunting of Parisian cafes in the 1920s; as he drank with his fellow aspiring artists, he says, "I realized that all the really good ideas I'd ever had came to me while I was milking a cow. So I went back to Iowa." ${ }^{8}$

Although Wood's self-conscious rusticity characterized the "artist in Iowa," away from Wood's Cedar Rapids studio, showed little of his

Hampl admired the Bilys' work, calling the clocks "intricate wooden sculptures" and "clock-epics in wood" (60).

6. James M. Dennis, Renegade Regionalists: The Modern Independence of Grant Wood, Thomas Hart Benton, and John Steuart Curry (Madison, WI, 1998).

7. Wanda Corn, "Grant Wood: Uneasy Modernist," in Grant Wood's Studio: Birthplace of American Gothic, ed. Jane Milosch (Munich, 2005), 113.

8. Cited in Brady M. Roberts, "The European Roots of Regionalism: Grant Wood's Stylistic Synthesis," in Grant Wood: An American Master Revealed, ed. Brady Roberts et al. (San Francisco, 1995), 32.

9. Artist in Iowa: A Life of Grant Wood is the title of Darrell Garwood's early mass-market biography (New York, 1944). 
influence. Their clocks display an almost paradoxical blend of modernity, cosmopolitanism, and regionalism. Indeed, their clock collection underscores the extent to which terms such as modern and regionalist constrict what we see and understand about cultural production in this era. Immersed in representing the physical and historical manifestations of time, the Bilys, unlike Wood, worked as if the urbane and the rustic, the cosmopolitan and the provincial, and the technological and the traditional were not mutually exclusive categories. Thus, rather than looking at the clocks as a hobby enabled by the cyclical time of agricultural labor, in this essay I interpret their themes and visual details to emphasize the brothers' relationship to modernity - their consciousness of living in a rapidly changing world as well as their critical exploration of modernity's implications. They used clocks, I argue, as a canvas for expressing and exploring the dramatically altered experience of time and space created by twentieth-century technology.

The Bilys' use of timepieces and wood, instead of paint and brushes, bridged the regional and cosmopolitan and timeless and timely in two ways. Wood carving without clockwork has a long tradition in the Czech and Scandinavian cultures that predominated in northeast Iowa at the time. ${ }^{10}$ And, by 1913, when the brothers made their first clocks, mail-order catalogs offered an abundance of inexpensive, mass-produced clocks and watches - perhaps the very clock mechanisms that the Bilys used to turn the hand-carved cases into functioning clocks. ${ }^{11}$ The use of massproduced mechanisms was evidently a deliberate choice since they had the skills to make the entire clock, including the clock works, by hand - as they did with a large, untitled tall case

10. On wood carving as a Czech tradition in Iowa, see Marianne Trejtnar Klinsky, "Czech Heritage," The Iowan 19 (December 1970), 12-15. For Norwegian traditions, see Darrell D. Henning, Marion J. Nelson, and Roger L. Welsch, eds., Norwegian-American Wood Carving of the Upper Midwest: An Exhibition Assembled by Vesterheim, The Norwegian-American Museum (Decorah, 1978). Alan Jabbour discusses the Bilys and other Iowa clock makers inspired by them in "Keeping Track of Culture: Grassroots Conservation," in Passing Time and Traditions: Contemporary Iowa Folk Artists, ed. Steven Ohrn (Des Moines and Ames, 1984), 149-59.

11. For a discussion of the sale and marketing of mass-produced timepieces, see Michael O'Malley, Keeping Watch: A History of American Time (Washington, DC, 1990), 145-99, esp. p. 184. 
clock they created around 1930. By clothing a mass-produced commodity in an elaborate handmade case, they confounded distinctions between machine-made and hand-created much as the European avant-garde - such as Marcel Duchamp — did in the 1910s and 1920s. Although they chose to keep their clocks in rural Spillville, I argue that thanks to their imaginative engagement with modernity, the Bily brothers did not see themselves as entirely submerged in Dvořák's bucolic retreat. Rather, they saw themselves as cosmopolitan regionalists, artists engaged with Iowa and the rest of the world.

DURING THEIR FIRST TEN YEARS of carving, the Bilys purchased clock case designs created for hobbyists from mailorder purveyors. ${ }^{12}$ Yet they did not approach their work as craftsmen: they did not make their objects for use. Even before they fully mastered their craft or developed an artistic vision, they made their clocks for display. ${ }^{13}$ The designs they used featured more scroll (jig) saw work than carving, but the brothers quickly began to vary and enlarge them by adding their own hand-carved figures or bases. ${ }^{14}$ Although enormous relative to

12. As Hutchinson notes (xvi), these designs can still be purchased.

13. Many recent works explore the possibility of non-practical uses of craft, or, to put it another way, they question how integral the notion of use is to craft, a line of thought that ultimately blurs the distinction between art and craft in the way that the Bilys themselves did. For books focused on carving and woodwork, see Michael Owen Jones, The Hand Made Object and its Maker (Berkeley, CA, 1975), esp. chap. 2; Simon J. Bronner, Chain Carvers: Old Men Crafting Meaning (Lexington, KY, 1984), 69; and Julia S. Ardery, The Temptation: Edgar Tolson and the Genesis of Twentieth-Century Folk Art (Chapel Hill, NC, 1998), 38. Most recently, Richard Sennett, in The Craftsman (New Haven, 2008), 8, a book focused on craft, echoes the "art for art's sake" mantra by defining craft as work done "well for its own sake." Conversely, Glenn Adamson, in Thinking Through Craft (Oxford, 2007), argues that "craft," with its emphasis on use, needs to be recognized as the essence of art.

14. In this respect, the Bilys' artistic trajectory reverses that of Sarah Jane Kimball, described in Michael Lewis, "Stitching Together Meaning: Sarah Jane Kimball's Fancywork, Class, and Consumption in Late Nineteenth-Century Iowa," Annals of Iowa 59 (2000), 141-64. Lewis argues that Kimball, who eagerly decorated her home with handmade "fancywork," gradually placed her expressive energies into mail-order shopping, thereby making a "transition from an artifact creator to a catalog consumer" (164). The Bilys did the reverse as they became conscious of themselves as artists. 
the spaces that housed them, the clocks were miniatures of the monumental public clocks of European church towers and town halls. Crucially, the Bilys' additions reveal the importance they placed on time as a theme and how pervasively they intermingled American and European imagery. The local and the modern loom as gothic iconography. For example, the standard-issue design of their second piece, the 1913 Hall Clock evokes a gothic cathedral. The brothers' additions modernize and localize the work by adding three carved figures in modern dress with musical instruments - representatives of the Spillville town band - who emerge from the arched doorway on the hour. The 1915 Capitol Style Clock, with a case in the shape of a cathedral crowned by a single domed central tower, similarly Americanizes a European design by adding a wooden statue of George Washington in the entryway and twin American eagles atop shields decorated with stars and stripes. Shuttered windows on both sides of the clock face open to reveal a scene from the Battle of Bunker Hill and a depiction of Christopher Columbus's arrival in North America. Likewise, when the Bilys carved the Apostles' Clock in 1915-1916, they started with the pattern's gothic cathedral-esque case but altered it by placing the fretwork piece on a large pedestal of their own design. With handcarved images of Prague's town square, including its medieval astronomical clock (which features moving apostles to mark the hour), and Spillville's Saint Wenceslaus Church, the pedestal renders the ancestral home coexistent with Spillville, in the same plane of space and time. The Bilys' vast perspective also emerges in contrast to a photograph they owned of a Tall Corn Clock. The front of this tall case clock is decorated entirely with corn cobs, kernels, a cornucopia, and a clock face labeled "Iowa"; nothing places Iowa or farming in any larger context. ${ }^{15}$

Within a decade of undertaking clock case carving, the brothers' work was fully shaped by a secular, modern vision of time. Leaving behind cathedral-based mail-order patterns for hobbyists, in 1923 they began work on the clock that established them

15. The photograph, which only shows the front of the clock, is undated, and the only other information in the caption indicates that the clock was located in Lake Mills, Iowa. The name in the lower right corner, P. E. Bolstad, could indicate the creator, the photographer, or the owner. 
as artists: the American Pioneer History Clock, the first clock made entirely from their own design. The museum pamphlet notes that the clock "stands over eight feet tall and weighs more than 500 pounds. The design is a series of 57 panels representing events in American history." With this accomplishment, the brothers' confidence in their work evidently reached a turning point. Around that time, they began to display their clocks to the public. In 1926, when the collection became too large for the confines of a farmhouse parlor, they built an exhibition hall, charged a dime admission to each entrant, and sold postcards, plates, and other memorabilia. The WPA Guide to 1930s Iowa included the "clock farm" in its discussion of attractions. ${ }^{16}$

WITH THEIR MODEL T, the brothers could have traveled to exhibits in Cedar Rapids or witnessed the flourishing of modern architecture in nearby Mason City (made famous as the model for Meredith Willson's nostalgic "River City"), which commissioned Frank Lloyd Wright to design a bank and hotel for the town and also featured a neighborhood full of homes designed by the forward-thinking architects of Wright's firm (ca. 1910). But a picture of Frank Bily at the wheel of the model $\mathrm{T}$ shows him going nowhere: he has driven into a field and parked there while Joseph poses on the running board (fig. 1). There is logic, then, in the clock museum story that constructs the brothers as rural Iowans above all and artists after that. Their work, however, indicates that they saw themselves as participants in a vast network of artists and thinkers traversing time and space in a way that humanists and artists have always used to define the cumulative progress of their work but also in a way new to the twentieth century. In other words, the Bilys participated in a cultural universe that encompassed not only their home but also an imagined republic of letters first posited by humanist ideals. The twentieth century's mass media and mass markets intensified the opportunities for the exchange of ideas and inspiration and brought the brothers the supplies they needed and the audience they wanted.

16. The WPA Guide to 1930s Iowa (1938; reprint, Ames, 1986), 347. 


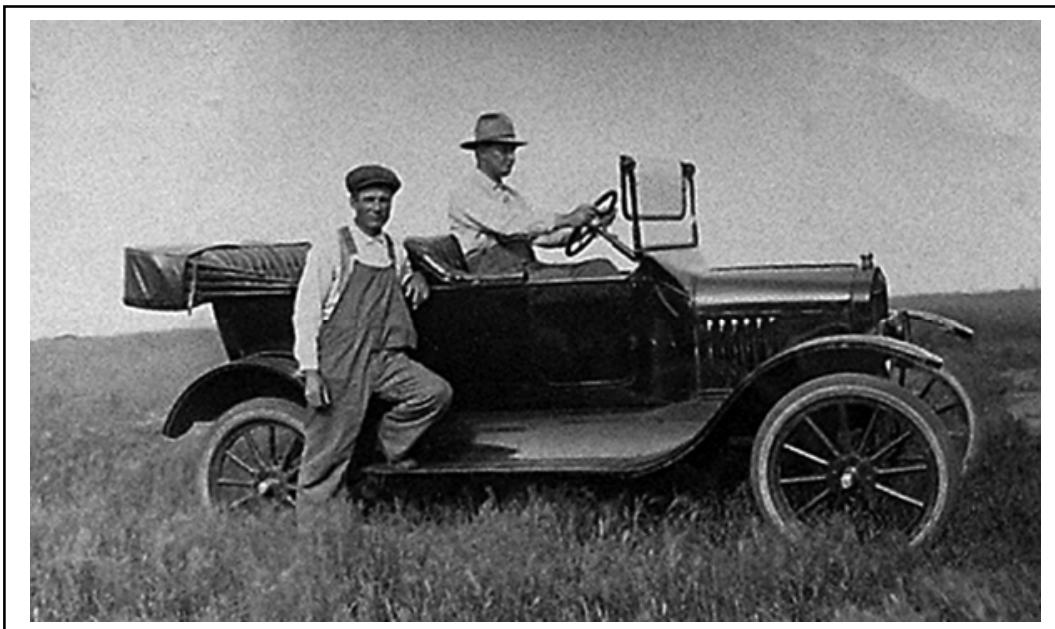

Figure 1. The Bilys with their car. Courtesy of the Bily Clock Museum.

The Bilys saw themselves as artists rooted in both Spillville and in a world that extended far beyond it. That vision emerges clearly in the contrast between Grant Wood's self-fashioning as a devoted Iowan and the Bilys' contemporaneous labors on the clock collection they titled the "Art of Wood-Carving" (fig. 2). The Bilys did enjoy some celebrity in their lifetime. They did not achieve fame on the level of Grant Wood, whose prize for American Gothic and the subsequent controversy about its meaning placed him in nearly every national news magazine. ${ }^{17}$ Nor did their reputation endure, as Wood's did. But the brothers had a steady stream of visitors, sometimes 1,000 in one day. Front-page cartoons from the Decorah Republican of the era commented on local tourism. One, captioned "Spring Invasion," showed an old farm couple on their front porch marveling at automobile-choked country roads (April 19, 1928); three months later, "Touring Season is On" depicted farm boys boasting about the varied license plates they have seen whiz by. ${ }^{18}$ Celebrities such as Cole Porter

17. Wood, with the help of his sister, Nan, carefully collected and commented on all the publicity he received. The scrapbooks can be consulted the Figge Museum of Art in Davenport, Iowa. I thank curator Michelle Robinson for allowing me to consult those materials.

18. Decorah Republican, 4/19/1928, 7/19/1928. 


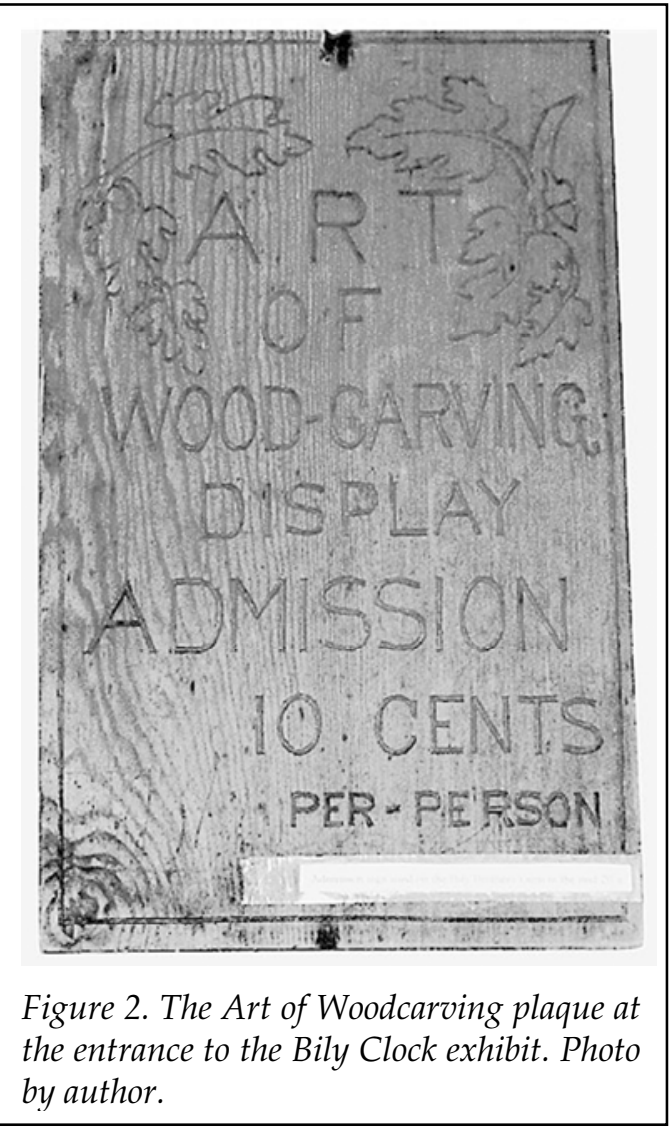

and Edward G. Robinson owned Wood paintings; the Bilys, on the other hand, garnered admiration by keeping their clocks at home. They turned down the opportunity to display their clocks at the 1933 Chicago World's Fair (which took as its theme the "Century of Progress"), and tour guides tell visitors that in 1928 the brothers refused Henry Ford's offer to buy their collection. ${ }^{19}$ Local newspapers reported on the Bilys' latest works and newest plans. The Mason City Globe-Gazette announced the beginning or completion of various clocks, and The Ford Times, a national magazine promoting automobile-based tourism, devoted a feature article to the collection in 1955, noting that "each year 40,000 people stop off in Spillville, Iowa, to see what time it is." ${ }^{20}$

19. I have not been able to document this offer, although Ford's agents did scout rural America in the 1920s for artifacts to display at Greenfield Village, Ford's living history museum, which opened in 1929. See Geoffrey C. Upward, ed., A Home for Our Heritage: The Building and Growth of Greenfield Village and Henry Ford Museum, 1929-1979 (Dearborn, MI, 1979). A collection of Spillville schoolchildren's essays about the Bily brothers contains one by Irene Benda, dated February 14, 1924, which states that the brothers refused a $\$ 1,000$ offer from an unnamed customer. "A Story in the History of My Community," vertical file, State Historical Society of Iowa, Iowa City.

20. Hutchinson, Bily Brothers; A. M. Wettach, “The Bily Brothers' Clocks," Ford Times, April 1955, 51. 
The publicity brought them an audience and an income, and their association with Dvořák gave them high-art prestige and perhaps calmed any desires to seek a more artistic milieu. The 1948 Violin Clock, carved by Joseph alone, suggests such a resolution. The composer's portrait dominates the center of the lower bout, and a clock face in the upper bout is adorned with the names of cities in which his works were played. Significantly, the caption on the base of the clock places Spillville at the center, if not the origins, of Dvořák's career. It gives the dates of his birth and death, but it does not note where those events took place. Only Spillville and Dvořák's 1893 sojourn there earn the glory of engraving (fig. 3).

Although the Violin Clock credits Spillville, rather than

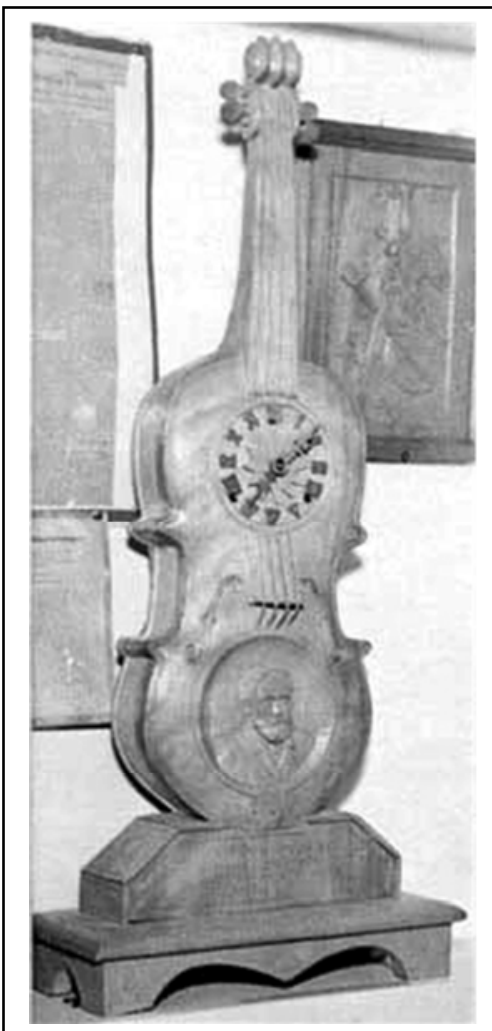

Figure 3. Postcard photo of the Violin Clock. Courtesy of author.

Europe, for Dvořák's artistic achievements, the Bilys were not blind to the limitations of their environs. Some of the most celebrated novels of their day portrayed the cultural deprivation of midwestern small towns. In Main Street (1920), Nobel Prize winner Sinclair Lewis portrayed a young woman's futile struggle to bring art to benighted Gopher Prairie, Minnesota. In Pulitzer Prize winner Willa Cather's My Antonia (1918), a cultured Czech immigrant succumbs to suicidal melancholia brought on by the hardship and isolation of Black Hawk, Nebraska. The Bilys express similar frustration in a note written on the cover of the 1945 Winnieshiek County Agricultural Association annual fair program. In a cloud that adorns the prairie landscape depicted at the top of the cover, one of the brothers wrote "no premium 


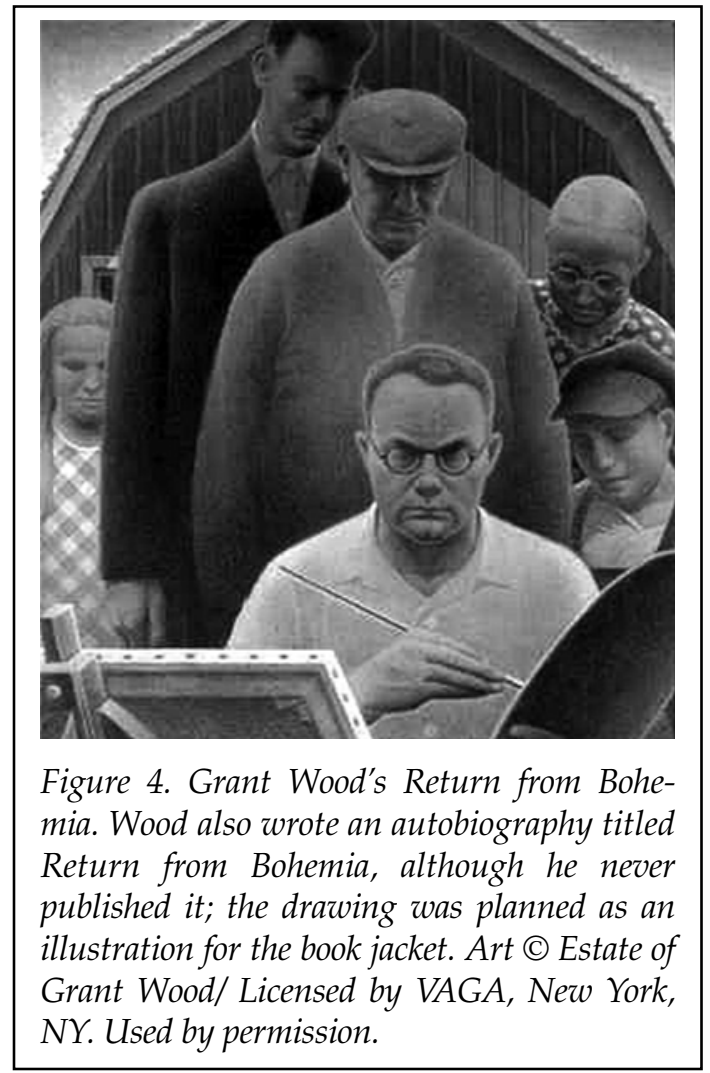

on art" and referred to page 114, where the text explains that since the exhibit's purpose is educational, ribbons will be given to the best booths put together by teachers in the various county townships, but that individual students will not be singled out for premiums. On that page, Frank or Joseph underlined "no premiums are given for individual articles exhibited" and wrote at the top and bottom of the page "In regard to art" - implying that pigs and preserves were better rewarded. ${ }^{21}$

21. This program can be found in one of several uncatalogued boxes of the Bilys' magazines and news clippings. These items are stored in bookcases on the second floor of the Bily Clock Museum in Spillville, along with shelves of mail-ordered plaster busts, evidently used as models for some of the wooden busts in the Statuary Clock. I thank Carol Riehle at the Bily Clock Museum for allowing me to examine these materials. 
In their art, however, the Bilys' view of Iowa was as expansive as the fair guide's depiction of the prairie horizon. A contrast between Grant Wood's 1935 self-portrait, Return from Bohemia (fig. 4) and the Bilys' Statuary Clock (1928-1930), an enormous cabinet crowded with labeled wood busts, full figure statues, and plaques (fig. $5)$, highlights the Bilys' capacious vision of Iowa's place in world culture. Both Wood and the Bilys experienced and internalized some frustration with provincial philistinism, but only Wood made the struggle part of his artistic identity. Iowa was the safe place to which he returned after his prodigal flings in Europe. His sister, Nan Wood, explained his state of mind by approvingly citing a 1937 profile of the artist that appeared in Scribner's mag-

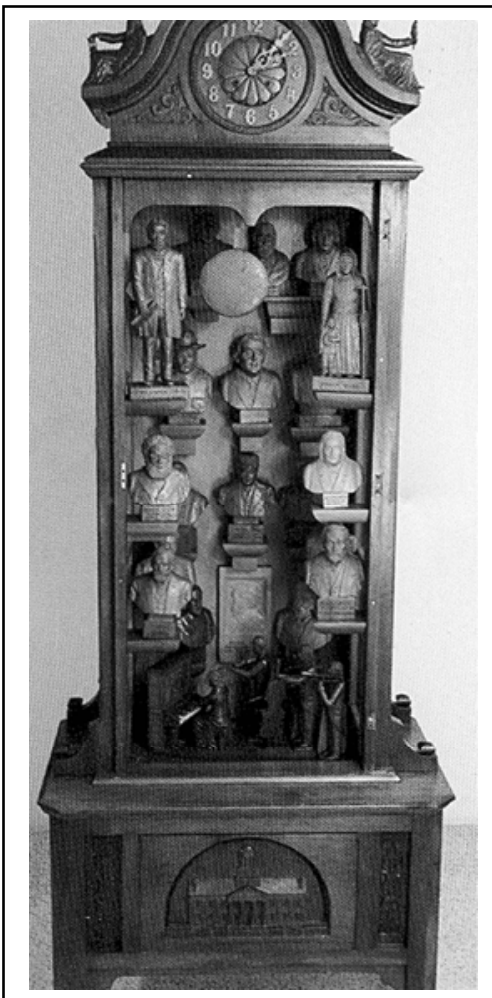

Figure 5. Postcard photo of the Statuary Clock. Courtesy of author. azine. The author, Thomas Craven, explained that Wood was "a victim of that old and snobbish superstition that a man cannot become an artist without submerging his personality in European ideas and conforming to the theories and practices prescribed by a colony of Bohemian esthetes."22 By returning from Bohemia, ${ }^{23}$ Wood signaled his renunciation not of art but of the

22. Cited by Nan Wood Graham with John Zug and Julie Jensen McDonald in My Brother, Grant Wood (Iowa City, 1993), 44. Steven Biel, American Gothic: A Life of America's Most Famous Painting (New York, 2005), provides an accessible and detailed account of the way Wood transformed provincialism into regionalism.

23. The term Bohemia had been in use since at least the 1840s, when Henri Murger began using it in his stories and sketches about the artistic subcultures of Paris. For an intriguing discussion of American "Bohemias" in this era, see Christine Stansell's American Moderns: Bohemian New York and the Creation of a 
unconventional, rootless urban lifestyle of European artists and their American counterparts. Thus, upon his "return" to his roots, Wood depicts himself painting, almost glaring with determination, with his back to a barn. In contrast to this rustic composition, the Bilys use an ornate cabinet for the Statuary Clock with an image of Iowa City's Old Capitol at the base.

Note the arrangement of people in both works. In Wood's painting, a generation-spanning group of Iowans circle behind the artist as they gaze at his canvas. In 1931 Wood told the Cedar Rapids Gazette that he was planning a self-portrait in which "the background will be the usual loafing bystanders who find time to watch ... with contempt, scorn, and an I-know- I-could-do-itbetter look." ${ }^{24}$ It is worth observing, however, that some of them, particularly the older man standing directly behind the artist, resemble Wood himself. Unlike Wood, the Bilys do not portray themselves or any unappreciative onlookers in their Statuary Clock; instead, they range through history and geography for their cast: Shakespeare, Kant, two Dvořáks (Antonin, the composer, and Thomas, an early Spillville settler), Abraham Lincoln, Theodore Roosevelt, Henrik Ibsen, Richard Wagner, Tomas Masaryk ("First President of Czechoslovakia"), an unnamed "American pioneer woman," Joseph Spielman (Spillville founder), and J. J. Haug (the town's first postmaster). Some members of the Bilys' cast are European geniuses, others are American heroes, and yet others are the workaday European immigrants who settled the New World, in flight, like the Bilys' parents, from their oppressed and oppressive homelands, such as the real Bohemia. Crucially, the brothers establish no clear hierarchy: the busts sit on shelves ranged throughout the cabinet, and they can be arranged and rearranged in any order. With his title and subject matter, Wood's painting depicts his forsworn allegiance to Europe and modern art, whereas the self-taught Bilys ostensibly felt no need to limit themselves to their region by drawing such historic and geographic boundaries. Neither Wood nor the Bilys

New Century (New York, 2000). In spite of the title, Stansell also describes midwestern Bohemians, such as Floyd Dell and Susan Glaspell, who formed an enclave in Davenport in the 1910s (46-49). See also Biel, American Gothic, 61-68.

24. Cited by Wanda M. Corn in Grant Wood: The Regionalist Vision (New Haven, CT, 1983), 112. 
paid much sustained attention to the crises of the day, such as the world wars and economic depression, but the Bilys' sense of scale spanned a larger range of time and place than Wood's.

The Bilys displayed this unbounded perspective from the start of their carving career. Just as they brought twentieth-century Spillville into the mail-ordered, European-inspired clock case patterns they initially used, the Bilys modified published designs to incorporate their vision of an artistic community. The 1913-1914 Chimes of Normandy Clock, for example, was placed on a base featuring a relief of "Westminster Abbey." Side panels devoted to the muses of art and music confirm that the Bilys understood that the abbey, as a center of learning and a burial place for British rulers and artists, memorialized the accumulating achievements of a culture. Their Apostles Parade Clock (carved about five years after the

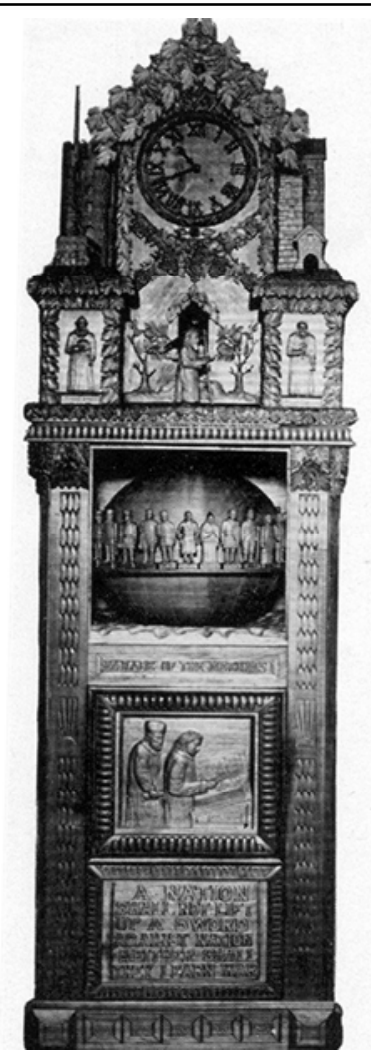

Figure 6. Postcard photo of the Parade of Nations Clock. Courtesy of author. Apostles Clock) also features these muses flanking Father Time. Later, several of their original designs were completely devoted to this theme. The Statuary Clock, discussed above, provides one example; the Parade of Nations Clock, another original design, carved about two years later, intensified their cosmopolitanism. With a traditional cuckoo clock at the peak, the center of the clock is dominated by an orbiting globe with 35 characters in varying national costumes circling the equator (fig. 6). Above this globe, on either side, are relief carvings of early modern cosmologists Tycho Brahe and Galileo. At the base of the cabinet, a biblical caption proclaims, "A nation shall not lift up a sword against nation[,] 


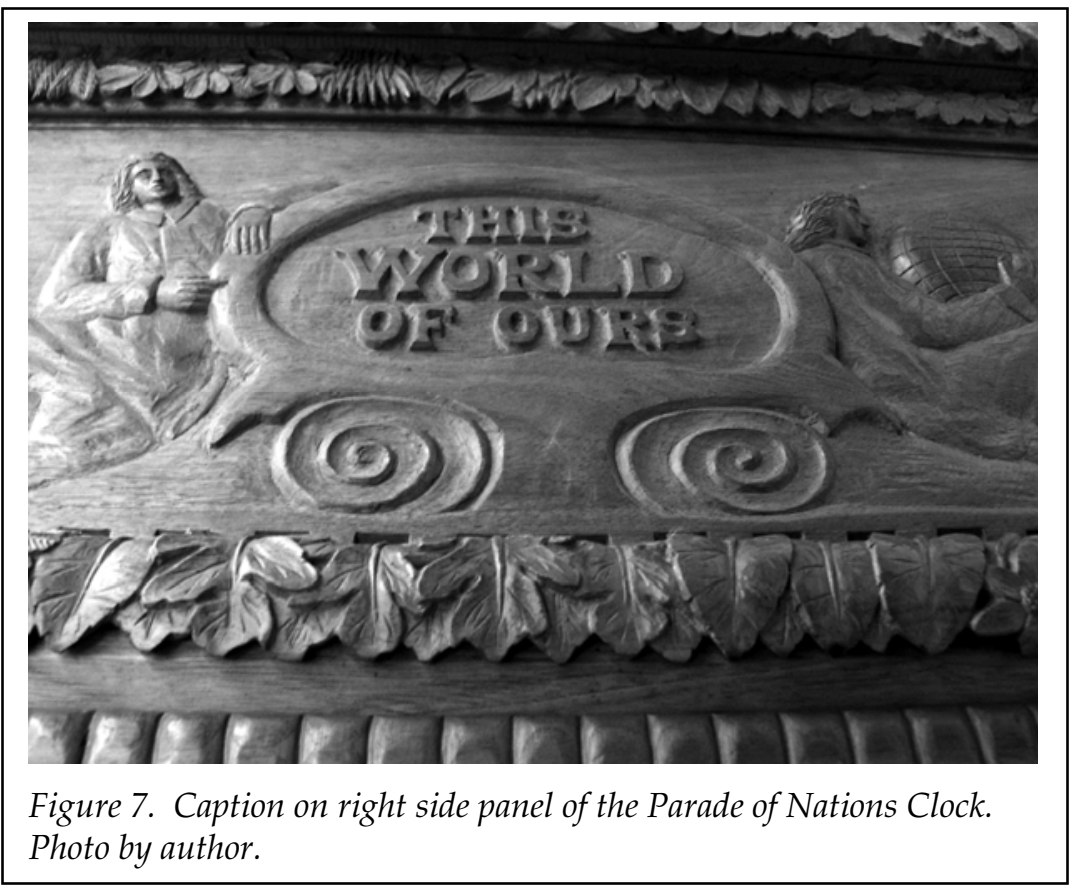

neither shall they learn war." The side panels depict a "history of education." In what may be the closest to a self-portrait the Bilys ever came, this history includes the Bilys' claim to cosmopolitan regionalism: a sign presenting "this world of ours" flanked by two men, one theatrically pointing to the sign and the other holding a large globe (fig. 7).

Their commitment to both modern ideals and Old World culture gives evidence of the sort of cosmopolitanism that cultural leaders, including Wood himself, deliberately excluded in their portrayals of the heartland. In contrast to the Bilys' ambition to portray myriad inhabitants and historical stages of "this world of ours," Grant Wood advocated not only a return to rural Iowa but also a "revolt against Literary Humanism" because of its "disproportionate emphasis on cultures of the remote past." The Bilys, on the other hand, were proud book collectors who signed the frontispieces in their volumes in elaborate cursive

25. Cited by E. Bradford Burns in Kinship with the Land: Regionalist Thought in Iowa, 1894-1942 (Iowa City, 1996), 17. 
(fig. 8); their library ranged through Iowa's State Parks and Preserves (1937), Immanuel Kant's Critique of Pure Reason (1781), and The Clock Book by Wallace Nutting (1924), which featured a photograph of Joseph Bily's Dvoŕák Clock as a frontispiece. They subscribed to American Art Student and Commercial Artist, American Carpenter and Builder, and Hobbies. They read the Des Moines Regis-

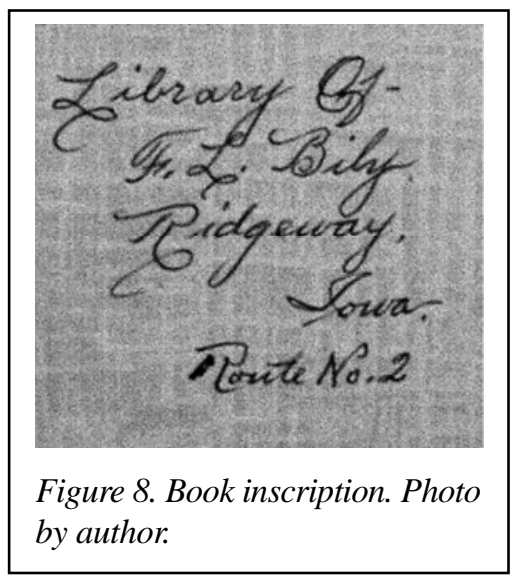
ter and local papers. They were curious about futurism, underlining the points that interested them in Christopher Nevinson and Filippo Marinetti's 1914 "Vital English Art: A Futurist Manifesto." Like the authors, the Bilys evidently shared a disdain for

6. The English notion that Art is a useless pastime, only fit for women and schoolgirls, that artists are poor deluded fools to be pitied and protected, and Art a ridiculous complaint, a mere topic for table-talk.

7. The universal right of the ignorant to discuss and decide upon all questions of art.

8. The old grotesque ideal of genius - drunken, filthy, ragged, outcast: drunkenness the synonym of Art. ${ }^{26}$

As farmers and carpenters, the brothers already fit the futurist ideal implied in this invective against bohemian stereotypes, while their reading materials connected them to a world beyond the village. Likewise, their admiration of venerated geniuses such as Kant and Shakespeare allowed them to share the mental time and space of the western humanist traditions that Wood deemed too remote (in both space and time) for artists in Iowa.

The futurist manifesto, even as it implicitly contrasted the rooted, hardworking artist to the outcast drunken genius, goes on to praise the modern phenomenon of speed and the new

26. This manifesto was printed in their copy (at the Bily Clock Musuem in Spillville) of W. Hugh Higginbottom, Frightfulness in Modern Art (New York, 1928), 129. 


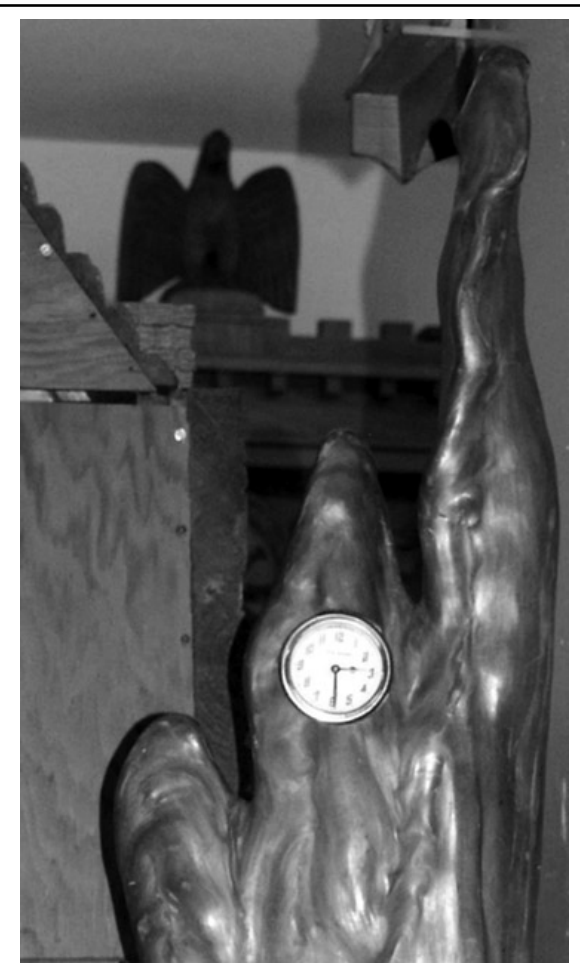

Figure 9. Untitled clock in the style of Dali. Photo by author. technologies that heightened it. The brothers further documented their interest in these issues by affixing clippings about clocks, clockmakers, and the nature of time to the blank pages in the fronts of their books. In Nutting's Clock Book, they stored an anonymous article philosophizing about time's importance. ("Time is not only the measure of life. It is the very stuff that life is made of.") A fastidiously clipped sentence fragment, stored in a book called Time and Timekeepers: Including the History, Construction, Care, and Accuracy of Clocks and Watches by Willis I. Milham (1923), both illustrates and exem-

plifies this interest: "streamlined passenger train, which shorten distance and race the clock." ${ }^{27}$ Their work, particularly their later clock designs, takes as a theme the experience epitomized by that "streamlined passenger train," a quintessentially modern phenomenon now called "space-time compression." The phrase describes the way new technologies shorten the time it takes to travel and to receive communication from distant points as well as the anxiety and fascination provoked by this ever increasing speed. $^{28}$

27. In the same book I also found pages from clock catalogs, two newspaper clippings about the 1730 invention of the cuckoo clock, articles about clock collectors, a photograph of Frank Bily, and a newspaper clipping about Strasbourg.

28. See Stephen Kern, The Culture of Time and Space, 1880-1918 (Cambridge, MA, 1983), 268. Geographer David Harvey builds on Kern's work in his key discus- 
Although time and distance can be experienced apart from clocks, the clock not only measures but also represents the modern experience of these abstractions. Iconic images of modernity, such as Charlie Chaplin laboring on a giant clock in Modern Times (1936), demonstrate the anxiety provoked by this mechanism. With a small untitled modernistic clock (fig. 9), the Bilys themselves echo the melting clocks in Salvador Dali's 1931 painting The Persistence of Memory. Conversely, in the home, supposed haven from this heartless world, the clock could be nostalgically

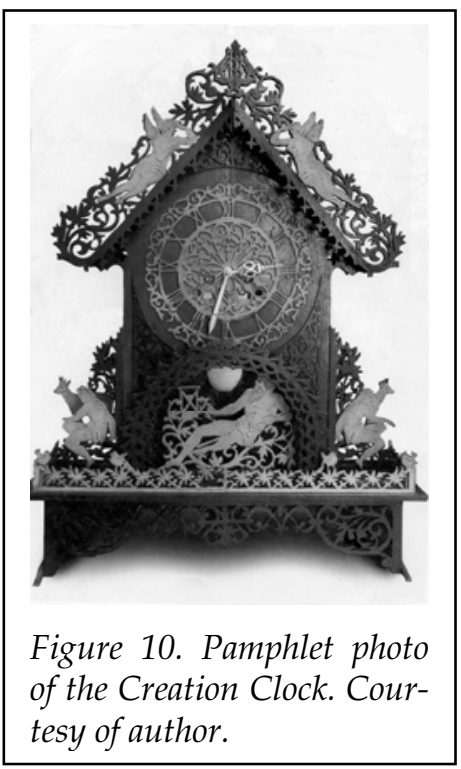
equated to the human heart as it was in Henry Clay Work's enormously popular song "My Grandfather's Clock," in which the machine stopped ticking on the day "the old man died." ${ }^{29}$ The Bilys conveyed all of these responses to time and its measure in their clocks.

THREE ASPECTS of these clocks illustrate how they were designed to reflect a specific interest in the modern experience of time, speed, and travel: the repeated representation of the clock face as a globe; clocks with transportation, travel, discovery and conquest as a theme; and, finally, as a rule-proving exception, the only overtly nostalgic clock, the Village Blacksmith (1942-1943).

The faces on the Bilys' mail-order clocks draw no attention to themselves, but many of their own designs replace unadorned circles with a detailed globe as the "face" or other prominent

sion of the role of space time compression in the formation of modern culture in his The Condition of Postmodernity: An Enquiry into the Origins of Cultural Change (Oxford, 1990), 260-83.

29. On the impact of this song, see John W. Finson, The Voices that Are Gone: Themes in Nineteenth-Century American Popular Song (Oxford, 1994), 124-33. 


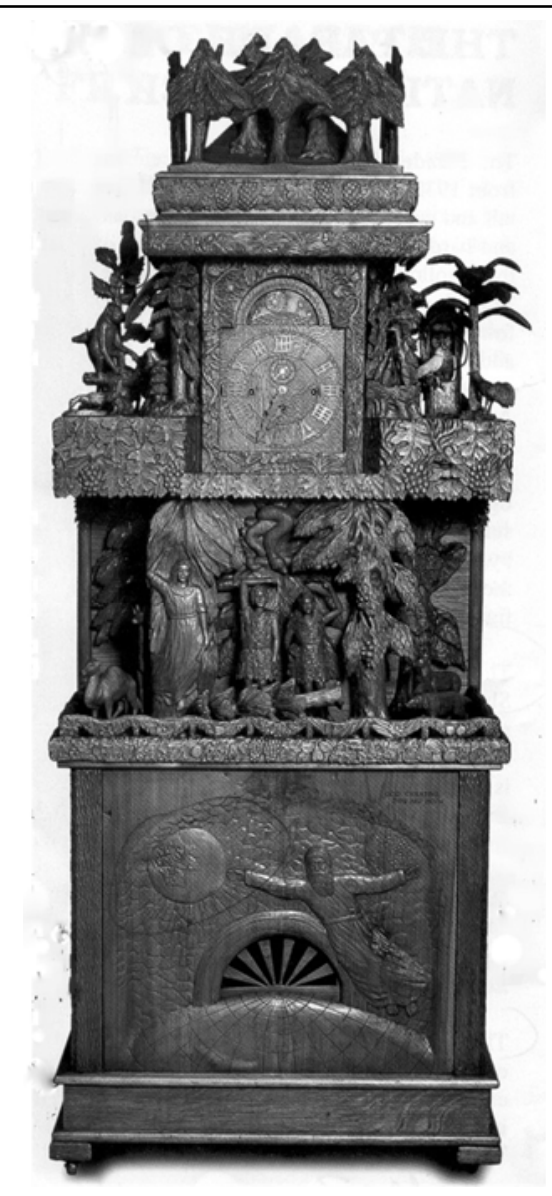

Figure 11. Pamphlet photo of the Paradise Clock. Courtesy of author.

design feature. Their first wholly original design, the Pioneer History Clock, shows an interesting transition from their purchased designs. The clock face sits in a tree with no visible leaves. Instead, the numbers orbit around a moon and star suspended in the branches. Four years later, in the 1928 Lindbergh Clock (shaped like an airplane and featuring a bust of the pilot), the clock face becomes a globe. The Struggle for Time Clock (1931-1932) also has a globe face, and a revolving globe dominates the Parade of Nations Clock (1932-1934). The Statuary Clock intensifies this technique and theme. The Bilys enlarged the pendulum swinging in this cabinet by making it into a globe nearly the same size as the clock face above it. The Paradise Clock from the mid-1930s culminates the Bilys' exploration of this theme as it revisits the subject of their first clock, 1913's Creation Clock. The early clock portrays little of the biblical creation myth, although a flat cutout figure who could be Father Time holds an hourglass beneath the lacy clock face. In contrast, the Paradise Clock imagines creation as a product of time meeting space, showing a profuse Eden with three tiers of forest stocked with palms, fruit trees, evergreens, and animals from diverse habitats. A globe floating in space tops the clock face, and the base cabinet, captioned "God creating the sun and the 
moon," shows the deity floating above the globe with the sun on the right hand and the moon on the left (figs. 10 and 11).

The Struggle for Time Clock (1929) is an oddity in the generally straightforwardly representational Bily collection (fig. 12). The museum pamphlet explains that this clock was inspired by the onslaught of automobiles arriving in Spillville to bring viewers to the collection, although it also evokes the horror of mortality. Interestingly, this clock portrays no form of locomotion except the inevitable hands of time. On the case, a pair of women and three men, separated by a free-floating nautical steering wheel, cower and

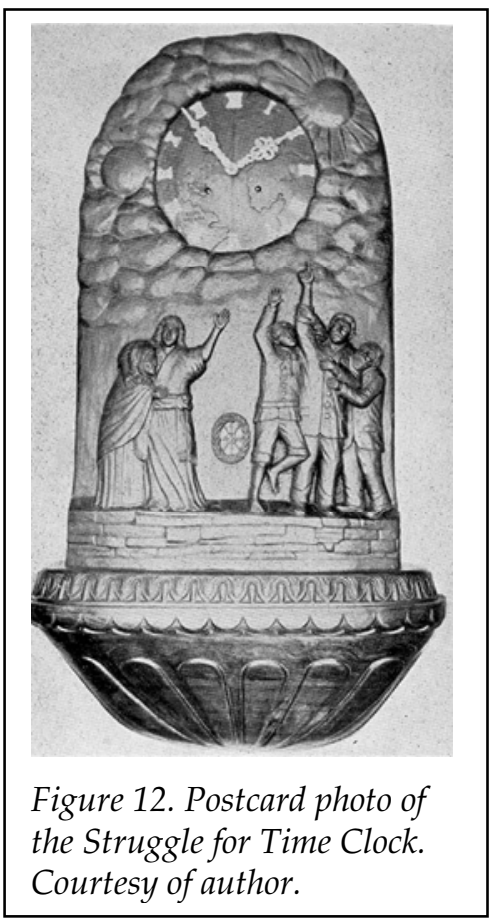
point to the sky, where a globe-faced clock and oppressive, boulder-like clouds diminish the moon and the sun. Adding to the sense of doom, the people stand on a brick floor or wall. Their costumes represent diverse periods of history: the women are dressed in nondescript ancient or medieval robes while two of the men wear more contemporary dress clothes. The third man, closest to the center of the clock, is barefoot yet dressed in a more old-fashioned suit with the pant legs rolled up. The male faces are distinct but unidentified. Except for the names of the continents on the clock face, there are no captions. Shaped like a tombstone, the clock seems to bemoan, rather than celebrate, the passage of time. Instead of depicting specific historical moments or artifacts, it offers an allegorical image of the cosmos as a prison guarded and doomed by a clock.

Ten years later, the History of Travel Clock (1939-1942) hints at a similar unease. It seems to glorify "The Lure of Speed," although the equivocal wording of the caption also expresses anxiety about the technology of time-space compression. "Lure" 


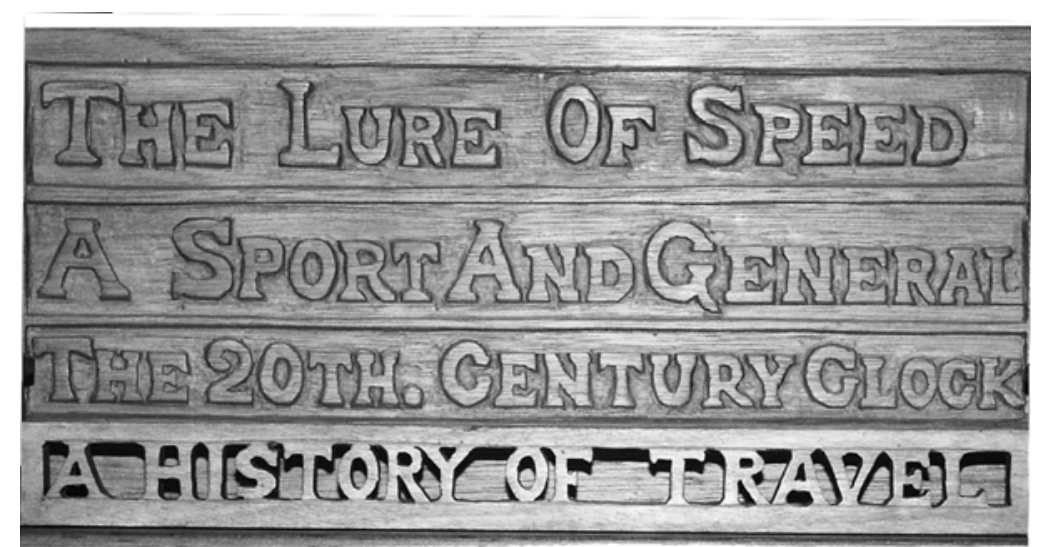

Figure 13. History of Travel Clock captions. Photo by author.

implies excitement and attraction, but also evokes temptation and entrapment. Another caption, for the 20th Century Clock, underscores the sense of culmination (fig. 13). The history begins with depictions of maritime explorers, then places land-based transport, such as horses, bicycles, and cars, above the waterbased vehicles, and finishes with air transport (a plane, a dirigible, a hot air balloon) floating around the clock face (here a sun). The clock emphasizes movement over arrival, but its details reveal a more disturbing theme. Carved during World War II, the airplane depicted on the clock is a military vehicle. The three ships portrayed at the bottom of the cabinet also mingle travel and conquest: they are captioned "Columbus," "early Americans" (natives in a canoe), and "Vikings." A small American eagle hovers over the caption while a huge one presides over the turreted cabinet; a marching band adds another note of triumphalism. This clock is about the possibility of going places, perhaps even about the possibility of conquering those places, but where those places are or how that "travel" affects the people who live in those places is not directly portrayed. That would be a different history of travel, something the largest caption, "A History of Travel," hints at with its interesting use of the indefinite article. This history stresses the increasing speed of conveyance; another history might explore the consequences of such travel. 
The History of Travel Clock indirectly portrays imperial conquest; another work from the late 1930s, On the Lookout[:] A Memorial to the American Pioneer, incorporates in one clock the dual perspective of progress and havoc, victory and defeat (fig. 14). Topped by an American Indian family emerging from a forest (in which a small clock is embedded), the case memorializes several civilizations. In size, placement, and three-dimensionality, the Indians dominate the design. Beneath them (separated by another brick wall motif) is a relief of a pioneer family traveling through the woods in a covered wagon. The

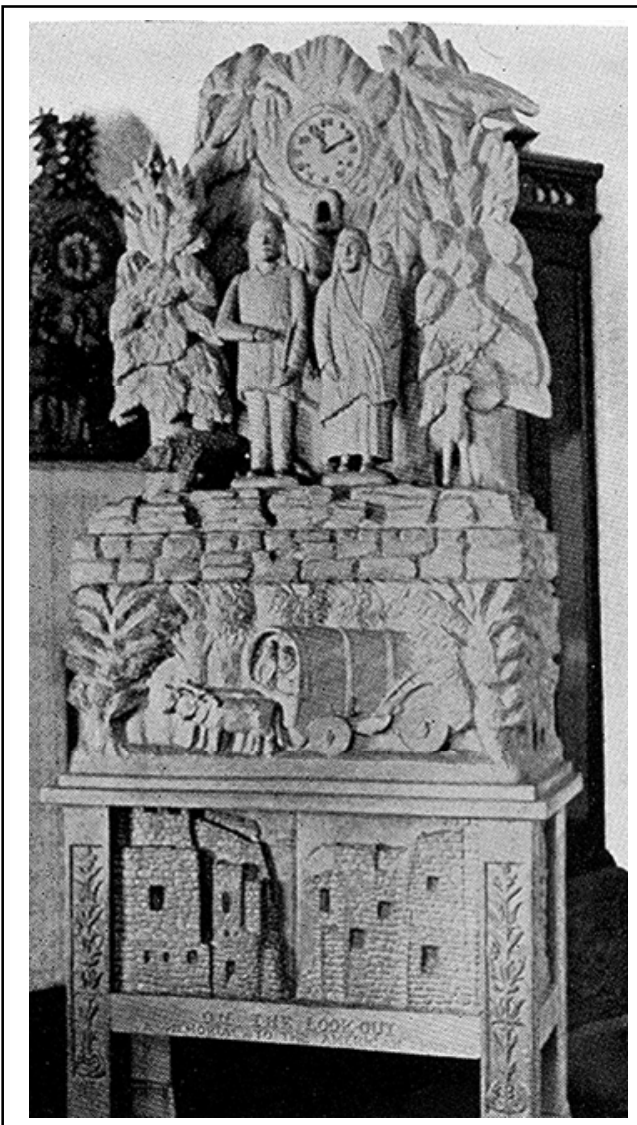

Figure 14. Postcard photo of On the Lookout Clock. Courtesy of author.

tree to their left holds a squirrel innocently chewing a nut; to their right, an eagle readies its wings to swoop. As if to note that this history repeats itself, the base cabinet shows an "Aztec Indian Village." The side panels feature representative woodwork from the Indians and the pioneers: a crude log cabin on the left panel and more elegant totem poles on the right. In many ways another version of their breakthrough, celebratory American Pioneer History Clock of the 1920s - in fact, the earlier clock is also captioned "Memorial to the American Pioneers" - On the Lookout mourns the conquered and displaced American Indian civilizations. 


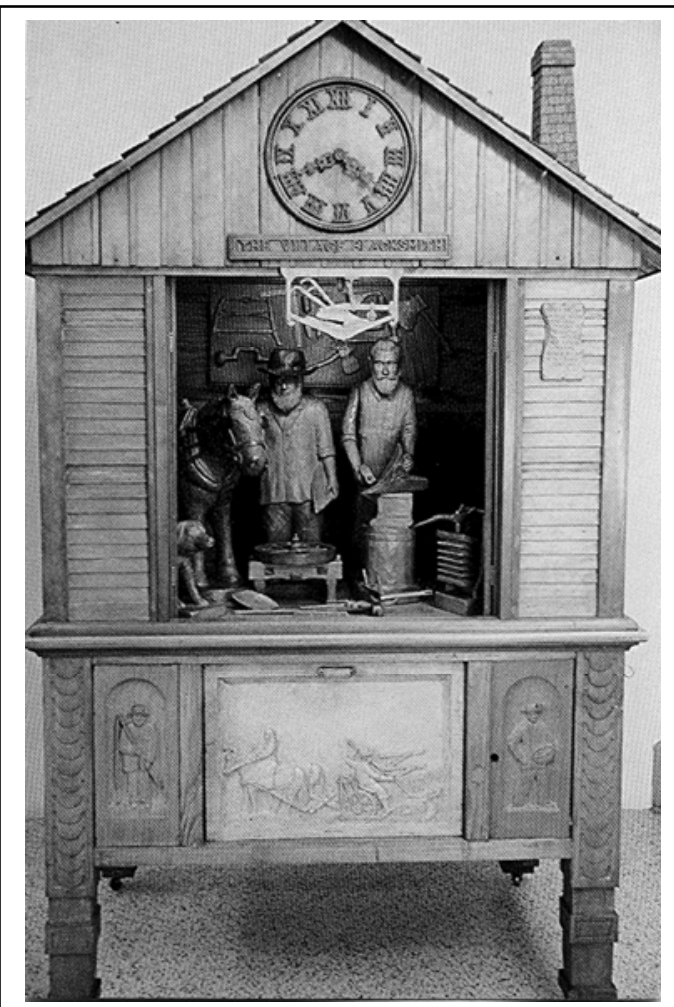

Figure 15. Postcard photo of the Village Blacksmith Clock. Courtesy of author.
The Village Blacksmith Clock, carved in 1942-1943, the last massive clock the brothers made (fig. 15), portrays the pioneer past as a sort of dollhouse. The museum pamphlet explains that "the famous first line of Longfellow's 1841 poem was the inspiration" for the clock. But just as the Bilys modified mailorder designs, they altered the image conjured by Longfellow's opening lines: "Under a spreading chestnut tree / The village smithy stands." The spreading chestnut tree is nowhere in sight: even the wood for the clock - butternut, birch, maple, and white oak - makes no reference to it. Furthermore, this village blacksmith seems to be an old man rather than the muscled young father with "crisp, and black, and long" hair that Longfellow describes. In other respects, though, the Bilys paid virtuosic attention to visual detail: the customer's straw hat is removable, the rivets on the fireplace hood show clearly, and deep in the shop a collection of detachable smithing tools hangs on the back wall.

A late addition to the clock, carved to look like a weathered broadside, hangs on the right side of the blacksmith's shop. (Early postcards do not show this feature.) Here, a (mis)quotation from Alexander Pope's "Ode on Solitude" (1735) makes an interesting thematic commentary on the Bilys' preoccupation 
with time, travel, and progress, as it seems to praise the opposite: "Happy the man whose wish and care content to breathe his native air a few paternal acres bound in his own ground" (fig. 16). The verb - "bound" places this happy man, like the blacksmith shop and its patrons, in the past. He is bound, perhaps buried, in his own ground. The correct quotation makes the temporality more equivocal since "by paternal acres bound" most likely modifies "wish and care" rather than "the man": "Happy the man whose wish and care / A few paternal acres bound, / Content to breathe his native air, / In his own ground." ${ }^{30}$ Pope praises the truly regionalist man who can gladly

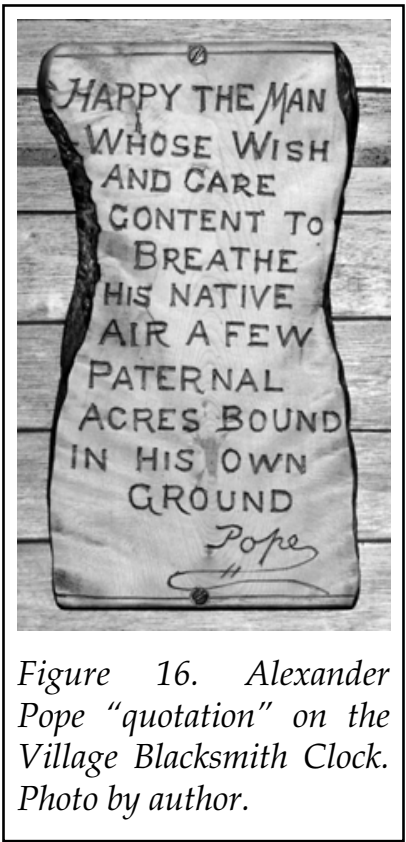
limit his horizon to his homestead; the Bilys place that possibility in the past. Rather than simply illustrating Longfellow's and Pope's poems, then, this clock documents the bygone era of old men, horse-drawn farming, and lives confined to a village. Appropriately, the clock makes no reference to traversing the globe and has an unornamented face, just simple roman numerals arranged in a circle.

IRONICALLY, not just the Village Blacksmith Clock, but now all of the clocks, bound to the Dvořák house and Spillville, have come to represent the slow pace and place of an agricultural past. But while they tended their paternal acres, and while Iowa's

30. Pope claimed to have written this poem when he was 12 years old (1700), and he published it in several versions over the course of his lifetime. No published version matches the Bilys' (mis)quotation, although one leaves out the "paternal acres" altogether, replacing it with "How happy he, who free from care / The rage of courts, and noise of towns; / Contented breathes his native air, / In his own grounds." For an account of the versions of this poem, see Dustin Griffin, "Revisions in Pope's 'Ode on Solitude,'" Modern Language Quarterly 36 (1975), 369-75. 
cultural image was dominated by Grant Wood's lovely rural landscapes and hard-bitten rustic portraits, the Bilys absorbed as much of the world and time as they could. To judge from their extensive portrayals of the shifting intersections of time and space, they imagined that modernity itself unbound them from their paternal acres, allowing them not only the possibility of carving out a cosmopolitan bohemia at home but also of representing that home to the rest of the world. Historians and critics may (or may not) ultimately deem other artists more talented than the Bilys, but their clocks, bound to Spillville, show how modernity affected Iowans and how Iowans, and the thousands of others who visited the museum, could simultaneously respond to modernity and evaluate their past. 